\title{
The Effects of Mobile Phone Use on Human Behaviors: A Study of Developing Country Like Bangladesh
}

\author{
Md. Mahbobor Rahaman \\ Lecturer, Leading University, Dept. of Business Administration, Sylhet-3100, Bangladesh \\ E-mail: mahbobdumis@gmail.com
}

Received: 03 June 2017; Accepted: 27 July 2017; Published: 08 November 2017

\begin{abstract}
The mobile phone is an essential part for human life all over the world. From developed to developing, developing to under developed countries are affected by the mobile phone usages, each and every corner of this universe. In every single minute we are using mobile phone for our various purposes. Even when there is no purpose we are also just using mobile phone. This scenario is almost same all over the world. The mobile phone has been affected the human behavior and changed the nature of behavior in developing countries. This paper has divided into three parts first part gathered information; second part analyses collected information and third part draw conclusions. In this paper, the result of the mobile phone used and effect on human behaviors in developing country like Bangladesh has been presented. This paper will also analyze this issue by exploring the exiting literature related to the mobile phone usages on human behavior and effect of the mobile phone on society in developing countries. Finally, this paper was presented some efficient solutions to minimize the problems in developing countries.
\end{abstract}

Index Terms-Mobile phone, Human behavior, Developing country, Bangladesh, Technology, Communication Systems.

\section{INTRODUCTION}

Today, mobile phone is very important part not only in developed countries but also in developing countries. Every single moment there is a need of mobile phone. From dawn to dusk mobile phone is must with us. In Bangladesh the culture of mobile phone is very new actually the use of mobile phone was started from the very beginning of 1990's. Mobile phone becomes very popular within a very short time in Bangladesh. About $85 \%$ of the people in Bangladesh are using the mobile phone now. From day laborer to the top class citizen have access on the mobile phone. From all around mobile phone is an essential element.

The impact of mobile phone is mixed on human behavior, someone say it has a positive impact and another negative impact. Mobile phone can highly have affected by the young generation all over the world. (Francke, 2007)

The total number of mobile phone users was117.758 in 2016 in Bangladesh ((BTRC), 2017). A huge number of mobile phone users are young generations and they are mostly affected by this device. The number of students was 2.4 million in JSC (bdnews24.com, 2016), 1.2 million in HSC (bdnews24.com, 2016), 1.65 million in SSC (bdnews24.com, 2016) and there is huge number of students are in the stage on graduation and under graduation levels. Moreover the others occupations people are using mobile phone for their daily conversation. Mobile phone is such kind of device which can affect the human behavior instantly in any place. There are two effects of mobile phone one is useful and another is harmful by the nature of users of this.

Mobile phone creates this world as bed of roses for all, when we are living in the post mobile age we have to face thousands of difficulties in each and every aspect of our life for an example to buy something we have to go to the market but mobile phones bring the market in our homes by the help of mobile commerce.

There are many people have been living in Bangladesh those cannot talk. Mobile phone brings the blessing for them, mobile phone introduce the text messing systems. By the blessing speechless people communicate with others.

Every day thousands of people are travelling all over the world and even in Bangladesh there are some many people are traveling in home and abroad. If they communicate in traditional post office service it will be very difficult to keep track with their friends and family members. But mobile phone creates an impossible thing as a possible one. Any one can communicate with each other in any part of the world.

Mobile phone can also make an emergency service by using mobile phone we can get the emergency service such as emergency ambulance, fire service or any other emergency which we have needed.

In this virtual world mobile phones are a part and parcel of our society. If we consider Bangladesh almost everyone has a phone of their own and it always see someone texting away or making a quick phone call or browsing internet or any other necessary, by touching or 
clicking. In Bangladesh each categories of people are using this miracle device for their daily activities without knowing the health hazard of this device and this device is affected the human behavior 24 hours in a day, each and every single second are affected by this device. Most of the people in Bangladesh find these to be extremely convenient resources for everyday life activities without considering the negative effects that cell phones could have on one's health and living environment.

Mobile phones are the simplest way to stay connected with friends, beloved ones, colleagues and family or keep track on the news and views or instantly knowing news around this universe, since cellular devices have become so advanced and sophisticated technology. It cannot be ignored that it can affect our human body and brain, social life, personal life, family life and even the global life standard. For example, the major form of communication in Bangladesh is mobile phone which already have become.

\section{OBJECTIVES OF THE STUDY}

Mobile phone in today's world is an essential part and parcel for each and every citizen in these virtual worlds. In developing countries like Bangladesh has a serious effect of mobile phone use. The main objective of this paper is the effect of mobile phone use on human behaviors in developing countries.

Moreover, the other key objectives of this study are

1. To identify the rate of dependency on mobile phone and rate of unawareness regarding the use of technology in developing countries like Bangladesh.

2. To identify the impact of mobile phone use on human behavior and how it impact on daily life of developing country's people.

3. To identify how rapidly changing the human behavior by using mobile technology or mobile phone in developing countries.

4. To identify impact of technology generally the mobile technology by the less educated people in developing countries.

\section{REASEARCH METHODOLOGY}

The research was divided into two stages, in the first stage a survey had conducted on the basis of close and open ended questionnaires.

In the second stage a frame for sampling was made all over the Bangladesh in where 609 respondents were selected as sampling size.

\section{A. Survey Design and Conduction of Survey}

The major source of data collection is survey. A close ended questionnaire is designed for collecting data. The questionnaires were divided in various sections which is related to the main objective of the research. There were secondary sources also used in this research for collecting the data. From the four divisions (Dhaka, Chittagong, Sylhet, Khulna) of Bangladesh data were collected by using various means such as face to face contract with respondents, e-mail communication, phone interview, survey, social media communications etc. To analyze the collected data SPSS 23 software were used.

\section{B. Study Areas and Sampling Frame}

Total 50 locations from four major divisions of Bangladesh are selected for conducting the survey, among them 10 locations from Sylhet, 10 locations from Khulna, 10 locations from Chittagong and 20 locations from Dhaka division. All the data were collected from the various locations of major four divisions of Bangladesh as a random way. That means from the Dhaka division we collected data randomly from various locations. In this study all levels or classes (educated, uneducated, employed, unemployed, professionals, rich, poor, students, house wife, farmer, service holder etc.) of people were included for collecting data. Data was designed for every one on an understandable way for example to collect data from a rickshaw puller we were used normal conversation on the basis of our questionnaire. Total 609 respondents among the four major divisions of Bangladesh were selected for collecting data and the study used the stratified sampling frame.

\section{RELATED WORKS}

The human behavior is rapidly changing with the touch of Information Technology all over the world. Technology is main key indicator of development of today's world. The effect of mobile phone on daily activities of a human being is affected the whole society and even the whole country. Bangladesh is a developing country and the vision of this country is to adapt the technology all over the country in all aspect. Though the introduction of mobile phone was started in 1990s, the effect of mobile phone is much more than any other in Bangladesh. Most of the people are using the mobile phone for their daily activities. Sometimes the mobile phone can change the behavior of human being.

Mobile addiction can be seriously affected at the psychological level of human mind and human organs (Goswami \& Singh, 2015). Many research was found the effective effect this change maker device. The mobile phones are not only communication devices but also used for news, information and others non formal communication media (Rajeev \& Jobilal, 2015).

The traditional form of communication is being obsolete day by day in developed country. In developing country there also almost the thing is happened. Mobile phone has both positive and negative consequences effect on the way that individuals function in society and it has a strong effect on human behavior and human psychology (Chatterjee, 2014).

The urban adolescents use mobile phones for a wide range of activities in their social activities (Nurullah \& Syed, 2011). There is a radical change on social contacts 
are replaced by virtual world contacts because of mobile phone usage in a wide range (Ling, 2011). There are many studies supporting the idea of media addictions to television and the Internet but research regarding mobile phone is very rare (Goswami \& Singh, 2015).

Most of the time the people are generally used the mobile phone more than any other task and even in some particular people are totally addicted by the mobile phone. Some studies found that driving while text messaging may be more dangerous than driving while under the alcohol influence (Oktay, 2006;Johnson, 2007 ;Dinesh, 2015; Campbell, 2005).

The beginning of the mobile phone invention normally this device was used by the adult, rich and highly educated man for their business or most vital public interest (Vasudev, Kaur, Kumar, \& Chaturvedi, 2012). The bad effect of mobile phone is so much serious not only on the way but also on the home. Human behavior is radically changed while user used mobile phone for their emotional moment (Dragutinovic \& Twisk , 2014).Mobile phone has some health hazards which can even cause cancer(Sanchez, 2006).

Physical and psychosocial exposure that can have effects on human health by the use of Information Communication Technology (ICT) in which include mobile phone and computer (Thomée, 2012).Mobile telephony has brought new possibilities all over the world even in Africa it brought a revolutionary change (Aker \& Mbiti, 2010). Mobile phones can change the behavior of teenagers in a rapid way ( ASHIQ, MAHMOOD, \& SIRAJ, 2013).Cell phone or mobile technology can be used to effectively tackle emergency situation to individuals as well as to larger population for analyzing the effective disaster management (Borkar \& Borkar, 2013).

The adaptation of mobile phone or mobile computing was initial in the beginning but it got the force from the some years later in Saudi Arabia (Alotaibi, 2015 ).By using mobile phone and mobile technology the personal ,social, governmental communication totally depended on this reliable technology but it has no long impact to development the human behavior (Campbell \& Park, 2008).Mobile phone provided many positive features but we cannot neglect the negative influences inherited in mobile phone, one of the most common negative sides of smart phones is their side effects on human health and behavior (Abu-Shanab \& Haddad , 2015).

Mobile phone even have a significant impact on education sector in Bangladesh (Rahaman \& Akter, 2017).Mobile phone specially smart phone have a great impact on our society and human behavior in all aspect the positive and negative effects of this devices are going together (Nath \& Mukherjee, 2015).In each and every country mobile phone is a popular device for communication (Vicente, Reis , \& Santos , 2008).The dark side of mobile phone is much more than the beneficiary side (Repacholi, 2001).Mobile can even change the culture (Wei \& Beth E. , 2005).

\section{DATAANALYSIS AND FINDINGS}

All the information which was collected from50 locations including remote areas in Bangladesh by designing a survey. In this study the researcher analyzed609 respondents from all over the Bangladesh. From demographic to economic to social to psychological all sides were analyzed by the IBM SPSS software.

The numbers of people are surveyed were 609 from various region of the Bangladesh. From the table 1 it was shown that all the people were using mobile phone those who were participating on this survey. Though the all people of Bangladesh are not using the mobile phone, the study need such kind of people those who use mobile phone. For this reason, the study focused on those people who were using mobile phone in Bangladesh.

Table 1. Do You Use the Mobile Phone?

\begin{tabular}{|c|c|c|c|c|}
\hline & Frequency & Percent & $\begin{array}{c}\text { Valid } \\
\text { Percent }\end{array}$ & $\begin{array}{c}\text { Cumulative } \\
\text { Percent }\end{array}$ \\
\hline Valid Yes & 609 & 100.0 & 100.0 & 100.0 \\
\hline
\end{tabular}

As our objectives is to gain the effect of mobile phone on human behavior generally in the developing country like Bangladesh so we collect all the data those who use mobile phone.

It was shown from the table 2 that $67.7 \%(412)$ male and $32.3 \%$ (197) female among the 609 people from the various region of Dhaka, Chittagong, Sylhet and Khulna division of Bangladesh. Most of the respondents were male (412 among 609), only 197 respondents were female because the number of mobile phone users in Bangladesh were male and they engaged with this device more than female portion. Most of the remote area's female respondents did not use mobile phone.

Table 2. Sex

\begin{tabular}{|c|c|c|c|c|c|}
\hline & & Frequency & Percent & $\begin{array}{c}\text { Valid } \\
\text { Percent }\end{array}$ & Cumulative Percent \\
\hline \multirow{3}{*}{ Valid } & Male & 412 & 67.7 & 67.7 & 67.7 \\
\hline & Female & 197 & 32.3 & 32.3 & 100.0 \\
\hline & Total & 609 & 100.0 & 100.0 & \\
\hline
\end{tabular}

Table 3. Age

\begin{tabular}{|c|c|c|c|c|}
\hline & Frequency & Percent & $\begin{array}{c}\text { Valid } \\
\text { Percent }\end{array}$ & $\begin{array}{c}\text { Cumulative } \\
\text { Percent }\end{array}$ \\
\hline 19-26 years & 453 & 74.4 & 74.4 & 74.4 \\
27-34 years & 83 & 13.6 & 13.6 & 88.0 \\
Valid $35-42$ years & 57 & 9.4 & 9.4 & 97.4 \\
43 to above & 16 & 2.6 & 2.6 & 100.0 \\
years & & & & \\
Total & 609 & 100.0 & 100.0 & \\
\hline
\end{tabular}

From the table 3 it was shown that $74.4 \%$ people were 19 to 26 years of age, $13.6 \%$ were 27 to 34 years of age, $9.4 \%$ were 35 to 42 years of age and only $2.6 \%$ of 
people were 43 to above of age. Among all the people of conducting survey maximum of them were young generations. This range of age are in their student life or they newly entered in to their service life and they try to spend more time on mobile phone so the ultimate effect of mobile phone is fallen on their life. In Bangladesh young generation were more affected by the mobile phone it was proved by the survey.

Table 4. Occupation

\begin{tabular}{|c|c|c|c|c|}
\hline & Frequency & Percent & $\begin{array}{c}\text { Valid } \\
\text { Percent }\end{array}$ & $\begin{array}{c}\text { Cumulative } \\
\text { Percent }\end{array}$ \\
\hline $\begin{array}{c}\text { Service } \\
\text { holder } \\
\text { Businessman }\end{array}$ & 127 & 20.9 & 20.9 & 20.9 \\
Valid & 30 & 4.9 & 4.9 & 25.8 \\
$\begin{array}{c}\text { Students } \\
\text { Farmers or } \\
\text { housewife }\end{array}$ & 382 & 62.7 & 62.7 & 88.5 \\
Others & 39 & 5.1 & 5.1 & 93.6 \\
Total & 609 & 100.0 & 100.0 & 100.0 \\
\hline
\end{tabular}

From the table 4 it was shown that $62.7 \%$ students, $20.9 \%$ service holders, $4.9 \%$ business man, $5.1 \%$ farmers or housewife, $6.4 \%$ others among the 609 surveyed people. About $84 \%$ students and service holders those use mobile phone for their daily conversation inside of Bangladesh or outside of Bangladesh. These two types of people had a great impact on our society, culture, politics, and economics and in a whole all sectors of Bangladesh. So the effect of mobile phone is much more if this two categories of people use mobile phone for their daily activities.

From the below table 5 it was shown that among the 609 respondent's education level were $5.3 \%, 6.9 \%, 59.4 \%, 25.8 \%$ and $2.6 \%$ respectively in Uneducated or below SSC to SSC, up to HSC, up to Honor's, up to Master's and PhD to above. Most of the respondents are Honor's and Master's level because most of the mobile phone users in Bangladesh were young generations they mostly used mobile phone.

Table 5. Educational Qualification

\begin{tabular}{|c|c|c|c|c|c|}
\hline & & Frequency & Percent & $\begin{array}{c}\text { Valid } \\
\text { Percent }\end{array}$ & $\begin{array}{c}\text { Cumulative } \\
\text { Percent }\end{array}$ \\
\hline \multirow{6}{*}{ Valid } & $\begin{array}{c}\text { SSC and } \\
\text { Below }\end{array}$ & 32 & 5.3 & 5.3 & 5.3 \\
\hline & Up to HSC & 42 & 6.9 & 6.9 & 12.2 \\
\hline & Up to Honor's & 362 & 59.4 & 59.4 & 71.6 \\
\hline & Up to Master's & 157 & 25.8 & 25.8 & 97.4 \\
\hline & PhD above & 16 & 2.6 & 2.6 & 100.0 \\
\hline & Total & 609 & 100.0 & 100.0 & \\
\hline
\end{tabular}

From the table 4 it was shown that $62.7 \%$ respondents were students because the maximum numbers of mobile phone users in Bangladesh were students. This portion of the users was highly affected by this midrace device. Other part of the users can cope up with the negative effect of the mobile phone. In Bangladesh the negative impact of mobile phone usage was very high in young generation.

Table 6. How long was you using mobile phone?

\begin{tabular}{|c|c|c|c|c|}
\hline & Frequency & Percent & $\begin{array}{c}\text { Valid } \\
\text { Percent }\end{array}$ & $\begin{array}{c}\text { Cumulative } \\
\text { Percent }\end{array}$ \\
\hline $\begin{array}{c}\text { 1 years to less } \\
\text { than 2 years } \\
\text { 2 years to less } \\
\text { than 3 years }\end{array}$ & 40 & 6.6 & 6.6 & 6.6 \\
Valid $\begin{array}{c}\text { 3 years to less } \\
\text { than 4 years } \\
\text { 4 years to } \\
\text { above } \\
\text { Total }\end{array}$ & 131 & 21.5 & 21.5 & 37.1 \\
\hline
\end{tabular}

Time spend on mobile phone is very important. In Bangladesh it was shown that from the above table 6 that $62.9 \%$ respondents (383 persons) were using more than four years. The user of mobile phone in Bangladesh is very consistent in using their mobile phone. Most of the mobile phone users have been using their mobile phone for a long period of time. From that data the effect of mobile phone in the behavior of human is highly affected by this device. Because each and every task (from the morning to night, from office to home, from university to home, class room to lab, road to room) in their daily life they use the mobile phone in various dimension. About $85 \%$ people were using mobile phone more than three years in Bangladesh so the people of this country have already affected and engaged by this miracle device.

Table 7. Which function of your mobile phone you used more?

\begin{tabular}{|c|c|c|c|c|c|}
\hline & & Frequency & Percent & $\begin{array}{c}\text { Valid } \\
\text { Percent }\end{array}$ & $\begin{array}{c}\text { Cumulative } \\
\text { Percent }\end{array}$ \\
\hline \multirow{6}{*}{ Valid } & Call & 199 & 32.7 & 32.7 & 32.7 \\
\hline & SMS & 64 & 10.5 & 10.5 & 43.2 \\
\hline & Internet & 291 & 47.8 & 47.8 & 91.0 \\
\hline & $\begin{array}{l}\text { Don't } \\
\text { Know }\end{array}$ & 29 & 4.8 & 4.8 & 95.7 \\
\hline & Others & 26 & 4.3 & 4.3 & 100.0 \\
\hline & Total & 609 & 100.0 & 100.0 & \\
\hline
\end{tabular}

From the table 7 it was shown that $47.8 \%$ respondents were using the internet facilities, $32.7 \%$ calling service, $10.5 \%$ SMS service and $4.3 \%$ other service among the 609 respondents. From the very begging of the mobile phone service in Bangladesh they were using the mobile phone only for call and SMS for a very few people. But now it was shown that in Bangladesh most of the mobile phone users are using the internet facilities that means users are spending more and more time in browsing the internet. To browse the internet there is need any helps of others even no need to talk with others. Most of the 
internet users via mobile phone were isolated from the main stream of the society. Most of the young generations of our country were spending more time on internet browsing so they were not engaged in various social works even in their family programs. Most of the young generations in Bangladesh were fully affected by the internet on mobile phone.

Table 8. How much time you spend with your mobile phone in a day?

\begin{tabular}{|c|c|c|c|c|c|}
\hline & & Frequency & Percent & $\begin{array}{l}\text { Valid } \\
\text { Percent }\end{array}$ & $\begin{array}{c}\text { Cumulative } \\
\text { Percent }\end{array}$ \\
\hline \multirow{6}{*}{ Valid } & $\begin{array}{l}1 \text { minute to } \\
20 \text { minutes }\end{array}$ & 25 & 4.1 & 4.1 & 4.1 \\
\hline & $\begin{array}{l}21 \text { minutes } \\
\text { to } 40 \\
\text { minutes }\end{array}$ & 99 & 16.3 & 16.3 & 20.4 \\
\hline & $\begin{array}{l}41 \text { minutes } \\
\text { to } 60 \\
\text { minutes }\end{array}$ & 77 & 12.6 & 12.6 & 33.0 \\
\hline & $\begin{array}{l}61 \text { minutes } \\
\text { to } 80 \\
\text { minutes }\end{array}$ & 120 & 19.7 & 19.7 & 52.7 \\
\hline & $\begin{array}{l}81 \text { minutes } \\
\text { to above }\end{array}$ & 288 & 47.3 & 47.3 & 100.0 \\
\hline & Total & 609 & 100.0 & 100.0 & \\
\hline
\end{tabular}

From the above table 8 among the 609 respondents $47.3 \%$ (288 respondents) were using their mobile phone more than 81 minutes in a day 2430 minutes in a month, 29160 minutes in a year. That means 20.25 days in a year most of the Bangladeshi mobile phone users spend with their mobile phone. So from the 365 days minimum 20.25 days were spending with mobile phone in Bangladeshi mobile phone users on an average.

Table 9. Do you think mobile phone is necessary for your life?

\begin{tabular}{|c|c|c|c|c|c|}
\hline & & Frequency & Percent & \begin{tabular}{|c|} 
Valid \\
Percent
\end{tabular} & $\begin{array}{c}\text { Cumulative } \\
\text { Percent }\end{array}$ \\
\hline \multirow{5}{*}{ Valid } & Strongly Agree & 321 & 52.7 & 52.7 & 52.7 \\
\hline & Agree & 229 & 37.6 & 37.6 & 90.3 \\
\hline & Neutral & 54 & 8.9 & 8.9 & 99.2 \\
\hline & $\begin{array}{l}\text { Strongly } \\
\text { Disagree }\end{array}$ & 5 & .8 & .8 & 100.0 \\
\hline & Total & 609 & 100.0 & 100.0 & \\
\hline
\end{tabular}

It was shown that from the table 9 the $52.7 \%$ strongly agree, $37.6 \%$ agree on the necessity of mobile phone in their life is very important and only $0.8 \%$ strongly disagreeing. So the necessity of mobile phone is vital in daily life of Bangladeshi people. Among the 609 respondents $90.3 \%$ respondents thought that mobile phone is necessary in their life in Bangladesh. As most of the respondents think this device is important for their life so it has affected their style of life and standard of living in the existing society.
Table 10. Do you think mobile phone sometimes make you a liar?

\begin{tabular}{|c|c|c|c|c|c|}
\hline & & Frequency & Percent & $\begin{array}{c}\text { Valid } \\
\text { Percent }\end{array}$ & $\begin{array}{c}\text { Cumulative } \\
\text { Percent }\end{array}$ \\
\hline \multirow{6}{*}{ Valid } & $\begin{array}{c}\text { Strongly } \\
\text { Agree }\end{array}$ & 92 & 15.1 & 15.1 & 15.1 \\
\hline & Agree & 218 & 35.8 & 35.8 & 50.9 \\
\hline & Neutral & 173 & 28.4 & 28.4 & 79.3 \\
\hline & Disagree & 83 & 13.6 & 13.6 & 92.9 \\
\hline & $\begin{array}{l}\text { Strongly } \\
\text { Disagree }\end{array}$ & 43 & 7.1 & 7.1 & 100.0 \\
\hline & Total & 609 & 100.0 & 100.0 & \\
\hline
\end{tabular}

From the above table 10 it was shown that $15.1 \%$ strongly agree and $35.8 \%$ agree, $28.4 \%$ neutral, $13.6 \%$ disagree and $7.1 \%$ strongly disagree on a question that do you think mobile phone sometimes make you a liar. About $51 \%$ of the total respondents thought that mobile phone sometimes makes them a liar. Conversation via mobile phone without sees any of them sometimes make wrong information. This harmful effect affected our society because this little habit one day makes a big trouble all over the country. This habit of ling is a very silly matter towards big problems not only in our society but also in Bangladesh.

Table 11. Do you think mobile phone sometimes separated you from society?

\begin{tabular}{|c|c|c|c|c|c|}
\hline & & Frequency & Percent & $\begin{array}{c}\text { Valid } \\
\text { Percent }\end{array}$ & $\begin{array}{c}\text { Cumulative } \\
\text { Percent }\end{array}$ \\
\hline \multirow{6}{*}{ Valid } & $\begin{array}{c}\text { Strongly } \\
\text { Agree }\end{array}$ & 89 & 14.6 & 14.6 & 14.6 \\
\hline & Agree & 261 & 42.9 & 42.9 & 57.5 \\
\hline & Neutral & 130 & 21.3 & 21.3 & 78.8 \\
\hline & Disagree & 99 & 16.3 & 16.3 & 95.1 \\
\hline & $\begin{array}{l}\text { Strongly } \\
\text { Disagree }\end{array}$ & 30 & 4.9 & 4.9 & 100.0 \\
\hline & Total & 609 & 100.0 & 100.0 & \\
\hline
\end{tabular}

Table 12. Do you think mobile phone sometimes separated you from Friends and Family?

\begin{tabular}{|c|c|c|c|c|c|}
\hline & & Frequency & Percent & $\begin{array}{c}\text { Valid } \\
\text { Percent }\end{array}$ & $\begin{array}{c}\text { Cumulative } \\
\text { Percent }\end{array}$ \\
\hline \multirow{6}{*}{ Valid } & $\begin{array}{c}\text { Strongly } \\
\text { Agree }\end{array}$ & 74 & 12.2 & 12.2 & 12.2 \\
\hline & Agree & 155 & 25.5 & 25.5 & 37.6 \\
\hline & Neutral & 184 & 30.2 & 30.2 & 67.8 \\
\hline & Disagree & 152 & 25.0 & 25.0 & 92.8 \\
\hline & $\begin{array}{l}\text { Strongly } \\
\text { Disagree }\end{array}$ & 44 & 7.2 & 7.2 & 100.0 \\
\hline & Total & 609 & 100.0 & 100.0 & \\
\hline
\end{tabular}


From the table 11 it was shown that mobile phone sometime separated ourselves from the society in here $14.6 \%$ strongly agree, $42.9 \%$ agree that means on an average $57.5 \%$ respondents were highly influenced by the mobile phone and its usages. Among the 609 respondents only $30(4.9 \%)$ respondents thought that mobile cannot affected them, they used the mobile phone only in where it was needed. From the data it was alarming not for Bangladesh but for developing country as well as that mobile phone has had a great impact on human life and their surrounding environments.

From the table 12 it was shown that $12.2 \%$ strongly agree, $25.5 \%$ agree, $30.2 \%$ neutral, $25 \%$ disagree and $7.2 \%$ strongly disagree on that mobile phone sometime separated themselves from the friends and family. From the data it was clearly concluded that mobile phone till not highly affected all the people and all the aspect of their human life in developing country like Bangladesh. There was another reason behind that most of the family members were using mobile phone for their daily activities that why they were somehow connected in a same way.

Table 13. Do you think mobile phone is blessing?

\begin{tabular}{|c|c|c|c|c|c|}
\hline & & Frequency & Percent & $\begin{array}{l}\text { Valid } \\
\text { Percent }\end{array}$ & $\begin{array}{c}\text { Cumulative } \\
\text { Percent }\end{array}$ \\
\hline \multirow{6}{*}{ Valid } & $\begin{array}{c}\text { Strongly } \\
\text { Agree }\end{array}$ & 120 & 19.7 & 19.7 & 19.7 \\
\hline & Agree & 301 & 49.4 & 49.4 & 69.1 \\
\hline & Neutral & 160 & 26.3 & 26.3 & 95.4 \\
\hline & Disagree & 24 & 3.9 & 3.9 & 99.3 \\
\hline & $\begin{array}{l}\text { Strongly } \\
\text { Disagree }\end{array}$ & 4 & .7 & .7 & 100.0 \\
\hline & Total & 609 & 100.0 & 100.0 & \\
\hline
\end{tabular}

There were so many good sides of mobile phone it was proved from the above table 13 , in this table it was shown that $19.7 \%$ strongly agree, $49.4 \%$ agree and $26.3 \%$ neutral on a question that do you think mobile phone is blessing. Most of the respondents were agree on that mobile phone is blessing for human life because mobile phone make the life easier than ever. So as a technological device it is blessing on the base of its usages.

Mobile phone is not a curse for the development of human being or the life of human being in developing country like Bangladesh. From the table 14 it was shown that only $9.2 \%$ respondents strongly agree and $19.7 \%$ agree that mobile phone is curse. But rest of them thought that mobile phone is not curse for them if it was used properly for their welfare. The negative side is totally depends on the users of the technology as the same way in Bangladesh the negative effect of mobile phone is depending on the age, educational qualification, surrounding environment, society and culture of the users.
Table 14. Do you think mobile phone is curse?

\begin{tabular}{|c|c|c|c|c|c|}
\hline & & Frequency & Percent & $\begin{array}{l}\text { Valid } \\
\text { Percent }\end{array}$ & $\begin{array}{l}\text { Cumulative } \\
\text { Percent }\end{array}$ \\
\hline \multirow{6}{*}{ Valid } & $\begin{array}{c}\text { Strongly } \\
\text { Agree }\end{array}$ & 56 & 9.2 & 9.2 & 9.2 \\
\hline & Agree & 120 & 19.7 & 19.7 & 28.9 \\
\hline & Neutral & 231 & 37.9 & 37.9 & 66.8 \\
\hline & Disagree & 142 & 23.3 & 23.3 & 90.1 \\
\hline & $\begin{array}{l}\text { Strongly } \\
\text { Disagree }\end{array}$ & 60 & 9.9 & 9.9 & 100.0 \\
\hline & Total & 609 & 100.0 & 100.0 & \\
\hline
\end{tabular}

From the table 15 it was shown that $19.7 \% \%$ respondents were strongly agree and $26.6 \%$ agree of a question that they spend more time with mobile phone than their friends and family members on an average. That means this study identified about $46.3 \%$ people thought they spend more time on mobile phone. Mobile phone has a strong impact on our society, community and country. This result indicated horrible news that human being was separated from the society as a result they were trying to think wild and harmful which can make a threat for human life in Bangladesh. One of the most important causes to increase crime in Bangladesh that most of the young generation spends their time on mobile phone not to engage on social works.

Table 15. Do you think you spend more time with mobile phone than your friends and family?

\begin{tabular}{|c|c|c|c|c|c|}
\hline & & Frequency & Percent & $\begin{array}{l}\text { Valid } \\
\text { Percent }\end{array}$ & $\begin{array}{c}\text { Cumulative } \\
\text { Percent }\end{array}$ \\
\hline \multirow{6}{*}{ Valid } & $\begin{array}{c}\text { Strongly } \\
\text { Agree }\end{array}$ & 120 & 19.7 & 19.7 & 19.7 \\
\hline & Agree & 162 & 26.6 & 26.6 & 46.3 \\
\hline & Neutral & 113 & 18.6 & 18.6 & 64.9 \\
\hline & Disagree & 154 & 25.3 & 25.3 & 90.1 \\
\hline & $\begin{array}{l}\text { Strongly } \\
\text { Disagree }\end{array}$ & 60 & 9.9 & 9.9 & 100.0 \\
\hline & Total & 609 & 100.0 & 100.0 & \\
\hline
\end{tabular}

Table 16. Do you think the time spends of your conversation on mobile phone is more than traditional conversation in your everyday life?

\begin{tabular}{|c|c|c|c|c|c|}
\hline & & Frequency & Percent & $\begin{array}{l}\text { Valid } \\
\text { Percent }\end{array}$ & $\begin{array}{c}\text { Cumulative } \\
\text { Percent }\end{array}$ \\
\hline \multirow{6}{*}{ Valid } & $\begin{array}{c}\text { Strongly } \\
\text { Agree }\end{array}$ & 28 & 4.6 & 4.6 & 4.6 \\
\hline & Agree & 208 & 34.2 & 34.2 & 38.8 \\
\hline & Neutral & 125 & 20.5 & 20.5 & 59.3 \\
\hline & Disagree & 204 & 33.5 & 33.5 & 92.8 \\
\hline & $\begin{array}{l}\text { Strongly } \\
\text { Disagree }\end{array}$ & 44 & 7.2 & 7.2 & 100.0 \\
\hline & Total & 609 & 100.0 & 100.0 & \\
\hline
\end{tabular}


From the table 16 it was shown that only $38.8 \%$ thought that they spend more time on mobile conversation than the traditional face to face conversation. These $38.8 \%$ respondents were totally isolated from our society and traditional form of communication in their daily life. But most of the respondents of the survey did not believe that they spend more time on mobile conversation. $33.5 \%$ disagree, $7.2 \%$ strongly disagree and $20.5 \%$ neutral that they spend less time on mobile conversation than traditional face to face conversation. Till now traditional conversation is much more popular and effective in communication.

Table 17. Do you think the conversation on mobile phone is more durable than traditional conversation?

\begin{tabular}{|c|c|c|c|c|c|}
\hline & & Frequency & Percent & $\begin{array}{c}\text { Valid } \\
\text { Percent }\end{array}$ & $\begin{array}{c}\text { Cumulative } \\
\text { Percent }\end{array}$ \\
\hline \multirow{6}{*}{ Valid } & $\begin{array}{c}\text { Strongly } \\
\text { Agree }\end{array}$ & 38 & 6.2 & 6.2 & 6.2 \\
\hline & Agree & 177 & 29.1 & 29.1 & 35.3 \\
\hline & Neutral & 112 & 18.4 & 18.4 & 53.7 \\
\hline & Disagree & 234 & 38.4 & 38.4 & 92.1 \\
\hline & $\begin{array}{l}\text { Strongly } \\
\text { Disagree }\end{array}$ & 48 & 7.9 & 7.9 & 100.0 \\
\hline & Total & 609 & 100.0 & 100.0 & \\
\hline
\end{tabular}

The conversation on virtual way is less durable than the conversation on physical way. From the above table 17 it was shown that only $6.2 \%, 29.1 \%$ were strongly agree and agree that the conversation on mobile phone is durable than the physical way. But among 609(46.3\%) respondents, 282 agree on that the conversation on mobile phone is less durable than the physical way. Most of the respondents in Bangladesh till now prefer to communicate on traditional or face to face way than mobile phone. The respondents thought that the durability of mobile phone conversation was less durable than the traditional physical communication or conversation.

In Bangladesh most of the people thought that they like to communicate on traditional way but the modern technology and easy life solution influence them toward this.

From the table 18 among the 609 respondents 136 $(22.3 \%)$ strongly agree and $281(46.1 \%)$ agree and (92) $15.1 \%$ neutral that means on an average $83.6 \%$ were highly affected on mobile phone and it could affect on their life style. From the table 18 it was shown that $68.5 \%$ respondents in Bangladesh thought mobile phone have a great influence on their life style and they were affected by this miracle device.

From the table 19 it was shown that 16 respondents of $\mathrm{PhD}$ or above from their educational qualification using mobile phone more than 4 years and 6 (they were senior citizen those who were not introduced in technology but modern age forced to use this mobile technology) of them using mobile phone more than 3 years. The respondents of master's level 141 among 158 using mobile phone more than 4 years that means they were young generation and fully engaged with technology. As the same way among the 362 respondents of honor's level 285 respondents using mobile phone more than 3 years from this data a huge number of young generations were engaged with modern technology and they influenced with mobile phone. From the table 19 there was also an alarming fact that among 32 respondents 12 of them were using mobile phone more than four years than means they using mobile phone from the early age. It has a great influence on these early aged respondents. Sometime they could not control the proper usage of mobile phone.

Table 18. Do you think mobile phone can effect on your life style?

\begin{tabular}{|r|c|c|c|c|}
\hline & Frequency & Percent & $\begin{array}{c}\text { Valid } \\
\text { Percent }\end{array}$ & $\begin{array}{c}\text { Cumulative } \\
\text { Percent }\end{array}$ \\
\hline $\begin{array}{c}\text { Strongly } \\
\text { Agree }\end{array}$ & 136 & 22.3 & 22.3 & 22.3 \\
Agree & 281 & 46.1 & 46.1 & 68.5 \\
Valid $\begin{array}{c}\text { Neutral } \\
\text { Disagree }\end{array}$ & 92 & 15.1 & 15.1 & 83.6 \\
Strongly & 20 & 3.3 & 3.3 & 100.0 \\
Disagree & 13.1 & 13.1 & 96.7 \\
Total & 609 & 100.0 & 100.0 & \\
\hline
\end{tabular}

Table 19. The relationship between educational qualification and how long they were using mobile phone

\begin{tabular}{|c|c|c|c|c|c|c|}
\hline & & \multicolumn{5}{|c|}{ How long was you using mobile phone? } \\
\hline & & $\begin{array}{l}1 \text { day to less } \\
\text { than } 1 \text { years }\end{array}$ & $\begin{array}{c}1 \text { years to less } \\
\text { than } 2 \text { years }\end{array}$ & $\begin{array}{c}2 \text { years to less } \\
\text { than } 3 \text { years }\end{array}$ & $\begin{array}{c}3 \text { years to less } \\
\text { than } 4 \text { years }\end{array}$ & $\begin{array}{c}4 \text { years to } \\
\text { above }\end{array}$ \\
\hline & & Count & Count & Count & Count & Count \\
\hline \multirow{5}{*}{$\begin{array}{l}\text { Educational } \\
\text { Qualification }\end{array}$} & SSC and Below & 0 & 2 & 6 & 12 & 12 \\
\hline & Up to HSC & 0 & 0 & 0 & 12 & 30 \\
\hline & Up to Honor's & 0 & 36 & 41 & 95 & 190 \\
\hline & Up to Master's & 0 & 2 & 2 & 12 & 141 \\
\hline & $\mathrm{PhD}$ to above & 0 & 0 & 6 & 0 & 10 \\
\hline
\end{tabular}




\section{RECOMMENDATIONS}

The researcher in this study had given some clear recommendations from all sides considering the nature of mobile phone use in the developing countries.

By analyzing the data from the societal, psychological, financial and political all aspects were described in details in this part.

\section{A. Recommendations from Societal side}

Mobile phones have become a very human attracting technological device not only in Bangladesh but also all over the world. In today's world it is uncommon for an individual not to own one mobile phone set. But the major fact that the use of mobile phones is diminishing moral value of today's society and is becoming a major issue in Bangladesh. Most of the people of Bangladesh believe that the increasing use of the mobile phone is improving society more and more every day in most of the aspects. Although, studies have shown that the excessive use of cell phones is ruining the social lives of the society. Cell phones are used on a daily basis, for most it is their whole live. The problem is that the society relies on this device for everything, they cannot live without it. This is playing a major factor in people's interaction with others and even worse; their relationships.

$>$ Social crimes are increasing by using mobile phone. We should be transparent in using mobile phone. Government should be realistic and proactive in making law regarding this issue.

$>$ Emotional disruption

$>$ By using mobile phone, we can enter any sit of the web; we should be strong in morality that we don't use our mobile phone for visiting any restricted sites.

$>$ Creating and building awareness among our young generations from the society to proper use of mobile phone.

\section{B. Recommendation from the Psychological side}

$>$ By taking the conversation via mobile phone male and female are trying to be a liar because any one cannot see them when they are in a conversation everyone should be transparent in their mobile conversation. They should be psychologically moral in using technology.

$>$ Emotional attachment with mobile phone is very easy practice in Bangladesh, normally in the young generations they easily lose their emotion via phone. All the users of mobile phone should be more aware while using mobile phone.

$>$ Radical change their behavior: Mobile phone can change the human behavior radically in their nature. Use mobile phone for self-development and self-prospect in such a way that mobile cannot affect their life style. In Bangladesh all the users of mobile phone are not aware about

$>$ This device. They should be aware about this matter.

\section{Recommendation from the Financial Side:}

$>$ Money is circulated every day because of mobile phone use.

> Mobile related industry should be established by taking government initiative that can create a smooth flow of money.

$>$ Mobile phone can be a huge source of employment opportunity in Bangladesh, directly or indirectly a large number of people can involve in this sector.

$>$ By using mobile phone in Bangladesh we can create a good flow of money circulation which can help to make a sustainable GDP for our country.

\section{Recommendation from the Political Side}

$>$ Political party in Bangladesh can use good side of mobile phone for their political agenda.

$>$ Political party can change the nature of any country; this party should use the mobile phone for the development of their country. In Bangladesh political party can use mobile phone for development of their country.

\section{CONCLUSION}

Mobile phone has a serious effect on human behavior generally in the developing and underdeveloped countries all over the world. It was mostly sure from the study that technology, in general, mobile phone or mobile technologies have a serious impact to change the human nature or human behavior because most of the people of developing and underdeveloped countries have an easy access to mobile technology or mobile phone. Technology is a new trend in this countries so they try to engage in and into with high enthusiastic mind. The psychology of third world countries were rapidly changing by using mobile phone or mobile technology. Most of the people were engaging with serious crime which was not only threat for Bangladesh but also all over the world without considering the economic solvency. The general people to criminal all of them were using the mobile phone for their necessity. The future scope of this study is how mobile phone can be a major changer of any human being each and every corner of this universe.

\section{ACKNOWLEDGMENT}

The author wish to express a special thanks to the all students of business administration department of Leading University Sylhet Bangladesh those who help me to collect data from various remote areas of Bangladesh. I also want to give a special think to my wife, Fatema Jannat Juhi, who gave me immense support for conducting a successful research.

\section{REFERENCES}

[1] ASHIQ, H., MAHMOOD, M., \& SIRAJ, S. A. (2013). Use of mobile communication and its affects on social 
capital of college going teenager. : International Journal of Research in Humanities, Arts and Literature, 1(3), 20-22.

[2] (BTRC), B. T. (2017, May 17). http://www.btrc.gov.bd/content/mobile-phone-

subscribers-bangladesh-august-2016. Retrieved May 17, 2017, from Bangladesh Telecommunication Regulatory Commission (BTRC): http://www.btrc.gov.bd/

[3] Abu-Shanab , E., \& Haddad , E. (2015, March-April). The Influence of Smart Phones on Human Health and Behavior: Jordanians' Perceptions. International Journal of Computer Networks and Applications, 2(2), 52-55.

[4] Aker, J. C., \& Mbiti, I. M. (2010). Mobile Phones and Economic Development in Africa. Center for Global Development, 4-8.

[5] bdnews24.com. (2016, 3 4). Retrieved May 17, 2017, from http://bdnews24.com/education/2016/04/03/morethan-1.2-million-students-taking-hsc-exams-for-2016: bdnews24.com

[6] bdnews24.com. (2016, May 11). Retrieved May 17, 2017, from bdnews24.com: http://bdnews24.com/bangladesh/2016/05/11/

[7] bdnews24.com. (2016, May 12). Retrieved May 17, 2017, from bdnews24.com: http://bdnews24.com

[8] Borkar, D., \& Borkar, S. (2013). Socio-economic impact of mobile phones. IOSR Journal Of Humanities And Social Science (IOSR-JHSS), 7(4), 17-19.

[9] Campbell, M. (2005). The Impact of the Mobile Phone on Young People's Social Life. Paper Presented to the Social Change in the 21st Century Conference., (pp. 1-4).

[10] Campbell, S., \& Park, Y. (2008). Social Implications of Mobile Telephony: The Rise of Personal Communication Societ. Sociology Compass, 380-382.

[11] Chatterjee, S. (2014). A Sociological Outlook of Mobile Phone Use in Society. International Journal of Interdisciplinary and Multidisciplinary Studies (IJIMS), 4(1), 59-63.

[12] Dinesh, G. (2015). Advertising and Promotion Campaigns as Branding Tools on Teenagers. Asian Journal of Research in Marketing., 1(2), 6-13.

[13] Dragutinovic , N., \& Twisk , D. (2014). Use of mobile phones while driving - effects on road safety. SWOV Institute for Road Safety Research, 5-9.

[14] Francke, E. a. (2007). South African Youth and Mobile Technology Impact. 9th Annual Conferance on World Wide Web Applications (pp. 1-19). Cap Town: The MXit Phenomenon Proceeding.

[15] Goswami, V., \& Singh, D. R. (2015). Impact of mobile phone addiction on adolescent's life: A literature review. International Journal of Home Science, 1(1), 72-73.

[16] Johnson, C. \&. (2007). National School Debate: Banning Cell Phones on Public School Campuses in America. National forum of Education Administration and Supervision Journal, 25(4), 1-6.

[17] Ling, R. (2011). The adoption, use and social consequences of mobile communication. . Telektronikk, $12-15$.

[18] Mutlaq B. Alotaibi,"Mobile Computing Trends in Saudi Arabia: An Exploratory Study", International Journal of Information Technology and Computer Science (IJITCS), vol.7, no.1, pp.21-32, 2015. DOI: 10.5815/ijitcs.2015.01.03

[19] Rahaman, M. M., \& Akter, N. (2017). ICT Used In Education Sector Considering Primary and Secondary Level Schools in Rural Areas: A Study of Sylhet Division in Bangladesh. IOSR Journal of Business and Management (IOSR-JBM), 19 (4), 1-06.

[20] Nath, D., \& Mukherjee, S. (2015, May). Impact of Mobile
Phone/Smartphone: A pilot study on positive and negative effects. International Journal of Advance Research in Computer Science and Management Studies, 3(5), 294300. Retrieved from www.ijarcsms.com

[21] Nurullah, A. S., \& Syed, S. F. (2011). Use of Mobile Phones and the Social Lives of Urban Adolescents: A Review of Literature. TRIM Journal, 1-5.

[22] Oktay, M. \&. (2006). Effects of Intensive and Moderate Cellular Phone Use on Hearing Function. Electromagn Biol Med, 25(1), 13-21.

[23] Rajeev, M., \& Jobilal . (2015). Effects of Social Media on Social Relationships: A Descriptive Study on the Impact of Mobile Phones among Youth Population. International Research Journal of Social Science, 4(2), 11-12.

[24] Repacholi, M. H. (2001). Health risks from the use of mobile phones. Toxicology Letters, 324-325.

[25] Thomée, S. (2012). ICT use and mental health in young adults. Effects of computer and mobile phone use on stress, sleep disturbances, and symptoms of depression . Department of Public Health and Community Medicine, Institute of Medicine, , 6-9.

[26] Vasudev, A., Kaur, M., Kumar, H., \& Chaturvedi, R. (2012, August). Mobile Phone Usage and Awareness of Health Related Issues Among the Male Science Students. CS Canada Studies in Sociology of Science, 3(3), 62-65.

[27] Vicente, P., Reis, E., \& Santos, M. (2008). Using mobile phones for survey research A comparison with fixed phones. International Journal of Market Research, 51(5), 613-615. doi:10.2501/S1470785309200852

[28] Wei, C., \& Beth E., K. (2005). Studying Mobile Phone Use in Context: Cultural, Political, and Economic Dimensions of Mobile Phone Use. 2005 IEEE International Professional Communication Conference Proceedings, (pp. 205-207).

\section{Authors' Profiles}

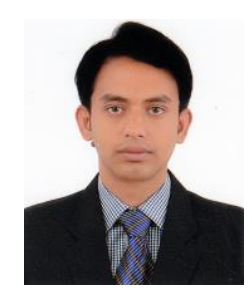

Md. Mahbobor Rahaman is currently working as a lecturer (MIS) at Leading University, Sylhet in Bangladesh. He has received his BBA degree in Management Information Systems from University of Dhaka in 2012 and MBA degree in Management Information Systems from University of Dhaka at 2014 in Bangladesh. He has been serving as a Lecturer in the major fields of Management Information Systems (MIS) at Leading University in Bangladesh since 2015.He is conducting various researches in the field of Information Technology for sustainable development, rural development, ICT for empowerment, ICT for women, women empowerment and other development sectors of Bangladesh. He is also working with technology and its use in the remote areas of Bangladesh.

How to cite this paper: Mahbobor Rahaman, "The Effects of Mobile Phone Use on Human Behaviors: A Study of Developing Country Like Bangladesh", International Journal of Information Technology and Computer Science(IJITCS), Vol.9, No.11, pp.48-56, 2017. DOI: 10.5815/ijitcs.2017.11.05 